\title{
Screening of Certain Chickpea Genotypes against Pulse Beetle, Callosobruchus chinensis (L.) under Laboratory Conditions
}

\author{
Kancherla Lakshmi Deepika, P.S. Singh* and S.K. Singh \\ Department of Entomology and Agricultural Zoology, Institute of Agricultural Sciences, \\ Banaras Hindu University, Varanasi-221005 (U.P.), India \\ *Corresponding author
}

\section{A B S T R A C T}

\begin{tabular}{|c|c|}
\hline & \multirow{4}{*}{$\begin{array}{l}\text { A laboratory experiment was conducted to determine the resistance of } 15 \text { chickpea } \\
\text { genotypes against pulse beetle, Callosobruchus chinensis (L.) under laboratory } \\
\text { conditions. The mean per cent weight loss ranged from } 62.48 \text { to } 33.92 \text { per cent. } \\
\text { The genotype PBG } 5(33.92 \%) \text { recorded minimum per cent weight loss followed } \\
\text { by GNG } 469(34.16 \%) \text { and these were identified as tolerant genotypes. Whereas, } \\
\text { the genotype Chaffa recorded highest per cent weight loss }(62.48 \%) \text { followed by } \\
\text { H } 82-2(\text { HC-1) }(49.04 \%) \text { and these were identified as susceptible. The mean per } \\
\text { cent damage was highest in the genotype JG } 11(50.50 \%) \text { and lowest in genotype } \\
\text { JG } 315(27.75 \%) \text {. }\end{array}$} \\
\hline $\begin{array}{l}\text { Screening, } \\
\text { Callosobruchus } \\
\text { chinensis, Chickpea }\end{array}$ & \\
\hline Article Info & \\
\hline $\begin{array}{l}\text { Accepted: } \\
10 \text { March } 2019 \\
\text { Available Online: } \\
10 \text { April } 2019\end{array}$ & \\
\hline
\end{tabular}

\section{Introduction}

Bearer Legumes are among the richest food source of proteins and amino acids for human and animal nutrition. India is the largest producer, consumer and importer of pulses in the world. In India Pulses are grown in around 24-26 million hectares of area, producing 1719 million tonnes of pulses annually. India accounts for over one third of the total world area and over 20 per cent of total world production, primarily producing Bengal gram (chickpeas), Red gram (tur), Lentil (masur), Green gram (mung) and Black gram (urad).

Chickpea is the third most important pulse crop, after dry bean and peas, produced in the world. It accounts for 20 per cent of the world pulse production. Majority of the pulses are susceptible to insect pests which is major constraint in the production, mainly because of improper management practices and unavailability of resistant genotypes to insect pests. Insect pests inflict severe losses both in the field and storage conditions (Mookherjee et al., 1970; Dias and Yadav, 1988).

Chickpea bruchid, Callosobruchus chinensis (L.) feeds on the chickpea and other peas. $C$. chinensis was declared as the major pest of chickpea, as it caused more than 10 per cent damage to it. During storage, high moisture content of grains $(>12 \%)$, high temperature $\left(25-35^{\circ} \mathrm{C}\right)$ and relative humidity $(>60 \%)$ make 
the environment very conducive for proliferation of insect pests (Adams, 1998). As a result, beetles develop rapidly and inflict substantial losses to grains. The grain characters, which also interfere the normal physiology or feeding of the insect, affects the biology of the pest adversely and these make a variety resistant to insect attack. Keeping these views in mind the present study was conducted to determine the resistance and susceptibility of certain chickpea genotypes under laboratory conditions.

\section{Materials and Methods}

A Laboratory experiment was conducted at the Insect Pest Management Laboratory, Department of Entomology, Institute of Agricultural Sciences, Banaras Hindu University, Varanasi during 2016-2017 for the estimation of losses caused by pulse beetle in stored chickpea. The culture of pulse beetle was maintained on chickpea seeds at room temperature in the Insect Pest Management Laboratory. Chickpea was procured from local market at Varanasi, it was cleaned, washed, dried and then sterilized at temperature of $50^{\circ} \mathrm{C}$ overnight to eliminate the hidden infestation.

The nucleus culture of $C$. chinensis was started by releasing 10 pairs of one day old adults in each glass jar $(25 \mathrm{~cm} \times 15 \mathrm{~cm} \times$ $10 \mathrm{~cm}$ ) containing 500 gram seeds for ovi position. After 48 hours adults were removed from the jars and discarded. The jars were covered with muslin cloth and tied up with rubber bands. These jars were kept at ambient condition in the laboratory. In order to get a continuous fresh supply of adults of C.chinensis for experimentation, culture was maintained at regular time intervals using the above rearing technique. During experimentation a pair of forceps, Camel hair brush and aspirator was invariably used for transferring insects in seeds (Fig. 1 and 2).

\section{Estimation of losses}

The losses caused by the pulse beetle in stored chickpea were determined and the details of experiment are given as under. For estimation of the losses in different genotypes, 5 pairs of adults (males and females) were released in separate jars containing $500 \mathrm{~g}$ chickpea seeds. The experiment was conducted in Completely Randomized Design (CRD) and replicated thrice. The observations given below were recorded at 30, 60, 90 and 120 days after release of adults of beetles.

\section{Mean grain damage (\%)}

Sample of $100 \mathrm{~g}$ chickpea seeds were taken from the jars of each replicate of every set after 30 days. The damaged seeds were separated out from the total number of seeds and taken for observation in each replication. Care was taken to avoid recount of damaged seeds. Suitable methods were adopted for observing the hidden infestation. The data taken was used for calculating the per cent seed damage. The same procedure was adopted for recording observations at 30, 60, 90 and 120 days after release of pulse beetle. The following formula was used for determination of per cent seed damage.

Mean Grain damage $=\frac{\text { Number of damaged Grains }}{\text { Total number of Grains counted }} \times 100$

\section{Mean weight loss (\%)}

After removing the beetles from each jar the weight of grains were taken separately on an electric balance from each replicate after 30 , 60,90 and 120 days of release. The mean per cent loss in weight was calculated by the following formula of (Dobie et.al., 1974).

Percentweightloss $=\frac{\mathrm{I}-\mathrm{F}}{\mathrm{I}} \times 100$ 
Where,

I $=$ Initial weight of seeds

$\mathrm{F}=$ Final weight of seeds

\section{Results and Discussion}

\section{Per cent weight loss}

The per cent weight loss in different genotypes after 30 days release of insects showed significant difference which varied between 2.28 to 37.71 per cent (Table 1). The maximum per cent loss in weight occurred in genotype Chaffa (37.71\%), followed by GNG -146 (15.63\%), H82-2(HC-10) (15.54 \%) and the lowest per cent weight loss recorded in RSG-902 (2.28 \%).

The per cent weight loss in different genotypes after 60 days release of insects showed significant difference which varied between 19.94 to 56.70 per cent (Table 2). The maximum per cent loss in weight occurred in Chaffa $(56.70 \%)$, followed by JG-11 (52.40\%), and the lowest per cent weight loss recorded in PBG-5 (19.94\%). The per cent weight loss in different genotypes after 90 days release of insects showed significant difference which varied between 48.71 to 70.04 per cent.

The maximum per cent loss in weight occurred in Chaffa $(70.04 \%)$ and the lowest per cent weight loss recorded in DCP 92$3(48.71 \%)$. The per cent weight loss after 120 days of release of bruchids in different genotypes varied significantly from 59.85 to 85.47 per cent (Table 2).

The maximum loss in weight occurred in Chaffa $(85.47 \%)$. The mean per cent weight loss in different genotypes varied significantly ranged from 62.48 per cent to 33.92 per cent. The maximum per cent loss in weight occurred in Chaffa (62.48\%) and the minimum per cent weight loss was recorded on PBG 5 (33.92\%).

\section{Per cent damage}

The per cent damage in different genotypes after 30 days release of insects showed difference in their damage which varied from 5.00 to 14.00 per cent (Table 2). The maximum per cent damage occurred in JG-11 $(14.00 \%)$ and the minimum per cent damage recorded in JG 315 (5.00\%), DCP 92-3 (5\%). The per cent damage in different genotypes after 60 days release of insects showed significant difference in their per cent damage which varied from 14.00 to 36.00 per cent. The maximum per cent damage occurred in JG-11(36.00\%) followed by Chaffa $(35.00 \%)$ and the minimum per cent damage recorded in DCP 92-3 (14.00\%). The per cent damage in different genotypes after 90 days release of insects showed significant difference in their per cent damage which varied between 34.00 to 67.00 per cent. The maximum per cent damage occurred in JG-11 (67.00\%), and the minimum per cent damage recorded in JG 315 $(34.00 \%)$. Seeds of 15 different chickpea genotypes damaged by the $C$. chinensis after 120 days of release varied from 55.00 to 85.00 per cent. Minimum per cent damage was recorded in DCP 92-3 (55.00\%), JG 315 $(55.00 \%)$. The genotype JG 11 recorded significantly highest damaged seeds $(85.00 \%)$. Mean grain damage of 15 different chickpea genotypes by the $C$. chinensis varied from 27.75 to 50.50 per cent. Minimum per cent damage was recorded in JG 315 $(27.75 \%)$. The genotype JG 11 recorded highest per cent seed damage $(50.50 \%)$ followed by Chaffa (48.75\%). The results are in close agreement with the findings of Patnaik and Samalo (1987), Khokhar and Singh (1987) who reported the seed infestation of pigeon pea genotypes by the bruchid in the range of 7.00 to 28.67 per cent, 5.16 per cent to 88.69 per cent, respectively. 
Table.1 Effect of pulse beetle on mean weight loss (\%) on different genotypes at different days of storage

\begin{tabular}{|c|c|c|c|c|c|}
\hline \multirow[t]{2}{*}{ Genotypes } & \multicolumn{5}{|c|}{ Weight loss per cent } \\
\hline & 30 Days & 60 Days & 90 Days & 120 Days & Mean \\
\hline H 82-2 (HC-1) & $\begin{array}{c}15.54 \\
(23.22)\end{array}$ & $\begin{array}{l}42.45 \\
(40.7)\end{array}$ & $\begin{array}{c}57.63 \\
(49.39)\end{array}$ & $\begin{array}{c}80.53 \\
(63.82)\end{array}$ & $\begin{array}{c}49.04 \\
(44.45)\end{array}$ \\
\hline Annegeri-1 & $\begin{array}{c}13.86 \\
(21.85)\end{array}$ & $\begin{array}{l}40.44 \\
(39.5)\end{array}$ & $\begin{array}{c}53.92 \\
(47.25)\end{array}$ & $\begin{array}{c}75.89 \\
(60.60)\end{array}$ & $\begin{array}{c}46.03 \\
(42.72)\end{array}$ \\
\hline Vikas & $\begin{array}{c}7.21 \\
(15.58)\end{array}$ & $\begin{array}{l}23.66 \\
(29.1)\end{array}$ & $\begin{array}{c}57.22 \\
(49.15)\end{array}$ & $\begin{array}{c}69.07 \\
(56.21)\end{array}$ & $\begin{array}{c}39.30 \\
(38.82) \\
\end{array}$ \\
\hline JG-11 & $\begin{array}{c}5.39 \\
(13.42)\end{array}$ & $\begin{array}{l}52.40 \\
(46.4)\end{array}$ & $\begin{array}{c}58.05 \\
(49.63)\end{array}$ & $\begin{array}{c}78.58 \\
(62.43)\end{array}$ & $\begin{array}{c}48.60 \\
(44.20) \\
\end{array}$ \\
\hline RVG-203 & $\begin{array}{c}8.65 \\
(17.10)\end{array}$ & $\begin{array}{l}30.22 \\
(33.3)\end{array}$ & $\begin{array}{c}55.91 \\
(48.39)\end{array}$ & $\begin{array}{c}78.11 \\
(62.11)\end{array}$ & $\begin{array}{c}43.23 \\
(41.11)\end{array}$ \\
\hline GNG 146 & $\begin{array}{c}15.63 \\
(23.29)\end{array}$ & $\begin{array}{l}27.33 \\
(31.5)\end{array}$ & $\begin{array}{c}59.05 \\
(50.21)\end{array}$ & $\begin{array}{c}73.21 \\
(58.83)\end{array}$ & $\begin{array}{c}43.80 \\
(41.44)\end{array}$ \\
\hline Chaffa & $\begin{array}{c}37.71 \\
(37.89)\end{array}$ & $\begin{array}{l}56.70 \\
(48.8)\end{array}$ & $\begin{array}{c}70.04 \\
(56.82)\end{array}$ & $\begin{array}{c}85.47 \\
(67.59)\end{array}$ & $\begin{array}{c}62.48 \\
(52.23)\end{array}$ \\
\hline RSG 931 & $\begin{array}{c}13.94 \\
(21.92)\end{array}$ & $\begin{array}{l}35.68 \\
(36.7)\end{array}$ & $\begin{array}{c}54.10 \\
(47.35)\end{array}$ & $\begin{array}{c}77.96 \\
(62.00)\end{array}$ & $\begin{array}{c}45.42 \\
(42.37)\end{array}$ \\
\hline GNG 469 & $\begin{array}{c}7.34 \\
(15.72)\end{array}$ & $\begin{array}{l}19.98 \\
(26.5)\end{array}$ & $\begin{array}{c}49.46 \\
(44.69)\end{array}$ & $\begin{array}{c}59.85 \\
(50.68)\end{array}$ & $\begin{array}{c}34.16 \\
(35.76)\end{array}$ \\
\hline RSG 902 & $\begin{array}{c}2.28 \\
(8.69)\end{array}$ & $\begin{array}{l}24.36 \\
(29.6)\end{array}$ & $\begin{array}{c}55.85 \\
(48.36)\end{array}$ & $\begin{array}{c}66.08 \\
(54.38)\end{array}$ & $\begin{array}{c}37.14 \\
(37.55)\end{array}$ \\
\hline PBG-5 & $\begin{array}{c}5.57 \\
(13.66)\end{array}$ & $\begin{array}{l}19.94 \\
(26.5)\end{array}$ & $\begin{array}{c}48.97 \\
(44.41)\end{array}$ & $\begin{array}{c}61.19 \\
(51.47)\end{array}$ & $\begin{array}{c}33.92 \\
(35.62)\end{array}$ \\
\hline JG-315 & $\begin{array}{c}12.17 \\
(20.42)\end{array}$ & $\begin{array}{l}38.84 \\
(38.6)\end{array}$ & $\begin{array}{c}57.97 \\
(49.59)\end{array}$ & $\begin{array}{c}71.30 \\
(57.61)\end{array}$ & $\begin{array}{c}45.07 \\
(42.17)\end{array}$ \\
\hline CSJ-515 & $\begin{array}{c}8.69 \\
(17.15)\end{array}$ & $\begin{array}{l}32.60 \\
(34.8)\end{array}$ & $\begin{array}{c}55.07 \\
(47.91)\end{array}$ & $\begin{array}{c}77.82 \\
(61.90)\end{array}$ & $\begin{array}{c}43.55 \\
(41.29)\end{array}$ \\
\hline GL 769 & $\begin{array}{c}6.97 \\
(15.31)\end{array}$ & $\begin{array}{l}35.15 \\
(36.4)\end{array}$ & $\begin{array}{c}54.55 \\
(47.61)\end{array}$ & $\begin{array}{c}76.06 \\
(60.71)\end{array}$ & $\begin{array}{c}42.43 \\
(40.65)\end{array}$ \\
\hline DCP 92-3 & $\begin{array}{c}5.40 \\
(13.44)\end{array}$ & $\begin{array}{l}21.37 \\
(27.5)\end{array}$ & $\begin{array}{c}48.71 \\
(44.26)\end{array}$ & $\begin{array}{c}71.13 \\
(57.50)\end{array}$ & $\begin{array}{c}36.82 \\
(37.36)\end{array}$ \\
\hline S.Em \pm & 1.92 & 1.97 & 1.59 & 1.03 & 1.63 \\
\hline C.D $5 \%$ & 7.487 & 7.67 & 6.18 & 4.00 & 6.34 \\
\hline
\end{tabular}

Figures in parenthesis are arc sine values 
Table.2 Effect of pulse beetle on mean grain damage (\%) on different genotypes at different days of storage

\begin{tabular}{|c|c|c|c|c|c|}
\hline \multirow[t]{2}{*}{ Genotypes } & \multicolumn{5}{|c|}{ Per cent seed damage } \\
\hline & 30 days & 60 days & 90 days & 120 days & Mean \\
\hline H 82-2 (HC-1) & $\begin{array}{c}10.00 \\
(18.43)\end{array}$ & $\begin{array}{c}32.00 \\
(34.45)\end{array}$ & $\begin{array}{c}61.00 \\
(51.35)\end{array}$ & $\begin{array}{c}83.00 \\
(65.65)\end{array}$ & $\begin{array}{c}46.50 \\
(42.99)\end{array}$ \\
\hline Annegeri-1 & $\begin{array}{c}9.00 \\
(17.46)\end{array}$ & $\begin{array}{c}3000 \\
(33.21)\end{array}$ & $\begin{array}{c}59.00 \\
(50.18)\end{array}$ & $\begin{array}{c}81.00 \\
(64.16)\end{array}$ & $\begin{array}{c}44.75 \\
(41.99)\end{array}$ \\
\hline Vikas & $\begin{array}{c}600 \\
(14.18)\end{array}$ & $\begin{array}{c}19.00 \\
(25.84)\end{array}$ & $\begin{array}{c}40.00 \\
(39.23)\end{array}$ & $\begin{array}{c}58.00 \\
(49.60)\end{array}$ & $\begin{array}{c}30.75 \\
(33.68)\end{array}$ \\
\hline JG-11 & $\begin{array}{c}14.00 \\
(21.97)\end{array}$ & $\begin{array}{c}36.00 \\
(36.87)\end{array}$ & $\begin{array}{c}67.00 \\
(54.94) \\
\end{array}$ & $\begin{array}{c}85.00 \\
(67.21)\end{array}$ & $\begin{array}{c}50.50 \\
(45.29)\end{array}$ \\
\hline RVG-203 & $\begin{array}{c}7 \cdot 00 \\
(15.34)\end{array}$ & $\begin{array}{c}29.00 \\
(32.58)\end{array}$ & $\begin{array}{c}56.00 \\
(48.45)\end{array}$ & $\begin{array}{c}73.00 \\
(58.69)\end{array}$ & $\begin{array}{c}41.25 \\
(39.96)\end{array}$ \\
\hline GNG 146 & $\begin{array}{c}6.00 \\
(14.18)\end{array}$ & $\begin{array}{c}2000 \\
(26.57)\end{array}$ & $\begin{array}{c}45.00 \\
(42.13)\end{array}$ & $\begin{array}{c}69.00 \\
(56.17)\end{array}$ & $\begin{array}{c}35.00 \\
(36.27)\end{array}$ \\
\hline Chaffa & $\begin{array}{c}12.00 \\
(20.27)\end{array}$ & $\begin{array}{c}35.00 \\
(36.27)\end{array}$ & $\begin{array}{c}64.00 \\
(53.13) \\
\end{array}$ & $\begin{array}{c}84.00 \\
(66.42) \\
\end{array}$ & $\begin{array}{c}48.75 \\
(44.28) \\
\end{array}$ \\
\hline RSG 931 & $\begin{array}{c}8.00 \\
(16.43)\end{array}$ & $\begin{array}{c}29.00 \\
(32.58)\end{array}$ & $\begin{array}{c}57.00 \\
(49.02)\end{array}$ & $\begin{array}{c}74.00 \\
(59.34)\end{array}$ & $\begin{array}{c}42.00 \\
(40.40)\end{array}$ \\
\hline GNG 469 & $\begin{array}{c}8.00 \\
(16.43)\end{array}$ & $\begin{array}{c}29.00 \\
(32.58)\end{array}$ & $\begin{array}{c}56.00 \\
(48.45)\end{array}$ & $\begin{array}{c}78.00 \\
(62.03)\end{array}$ & $\begin{array}{c}42.75 \\
(40.83)\end{array}$ \\
\hline RSG 902 & $\begin{array}{c}7.00 \\
(15.34)\end{array}$ & $\begin{array}{c}25.00 \\
(30.00)\end{array}$ & $\begin{array}{c}52.00 \\
(46.15)\end{array}$ & $\begin{array}{c}70.00 \\
(56.79)\end{array}$ & $\begin{array}{c}38.5 \\
(38.35)\end{array}$ \\
\hline PBG-5 & $\begin{array}{c}7.00 \\
(15.34)\end{array}$ & $\begin{array}{c}31.00 \\
(33.83)\end{array}$ & $\begin{array}{c}57.00 \\
(49.02)\end{array}$ & $\begin{array}{c}74.00 \\
(59.34)\end{array}$ & $\begin{array}{c}42.25 \\
(40.54)\end{array}$ \\
\hline JG-315 & $\begin{array}{c}5.00 \\
(12.92)\end{array}$ & $\begin{array}{c}17.00 \\
(24.35)\end{array}$ & $\begin{array}{c}34.00 \\
(35.67)\end{array}$ & $\begin{array}{c}55.00 \\
(47.87)\end{array}$ & $\begin{array}{c}27.75 \\
(31.79)\end{array}$ \\
\hline CSJ-515 & $\begin{array}{c}8.00 \\
(16.43)\end{array}$ & $\begin{array}{c}28.00 \\
(31.95)\end{array}$ & $\begin{array}{c}55.00 \\
(47.87)\end{array}$ & $\begin{array}{c}72.00 \\
(58.05)\end{array}$ & $\begin{array}{c}40.75 \\
(39.67)\end{array}$ \\
\hline GL 769 & $\begin{array}{c}9.00 \\
(17.46)\end{array}$ & $\begin{array}{c}30.00 \\
(33.21)\end{array}$ & $\begin{array}{c}58.00 \\
(49.60)\end{array}$ & $\begin{array}{c}75.00 \\
(60.00)\end{array}$ & $\begin{array}{c}43.00 \\
(40.98)\end{array}$ \\
\hline DCP 92-3 & $\begin{array}{c}5.00 \\
(12.92)\end{array}$ & $\begin{array}{c}14.00 \\
(21.97)\end{array}$ & $\begin{array}{c}38.00 \\
(38.06)\end{array}$ & $\begin{array}{c}55.00 \\
(47.87)\end{array}$ & $\begin{array}{c}28.00 \\
(31.35)\end{array}$ \\
\hline S.Em \pm & 1.21 & 1.72 & 1.39 & 2.03 & 1.59 \\
\hline CD 5\% & 3.50 & 4.97 & 4.02 & 5.87 & 4.59 \\
\hline
\end{tabular}

Figures in parenthesis are arc sine values 
Fig.1 Chickpea seeds showing the Egg laying and damage done by pulse beetle
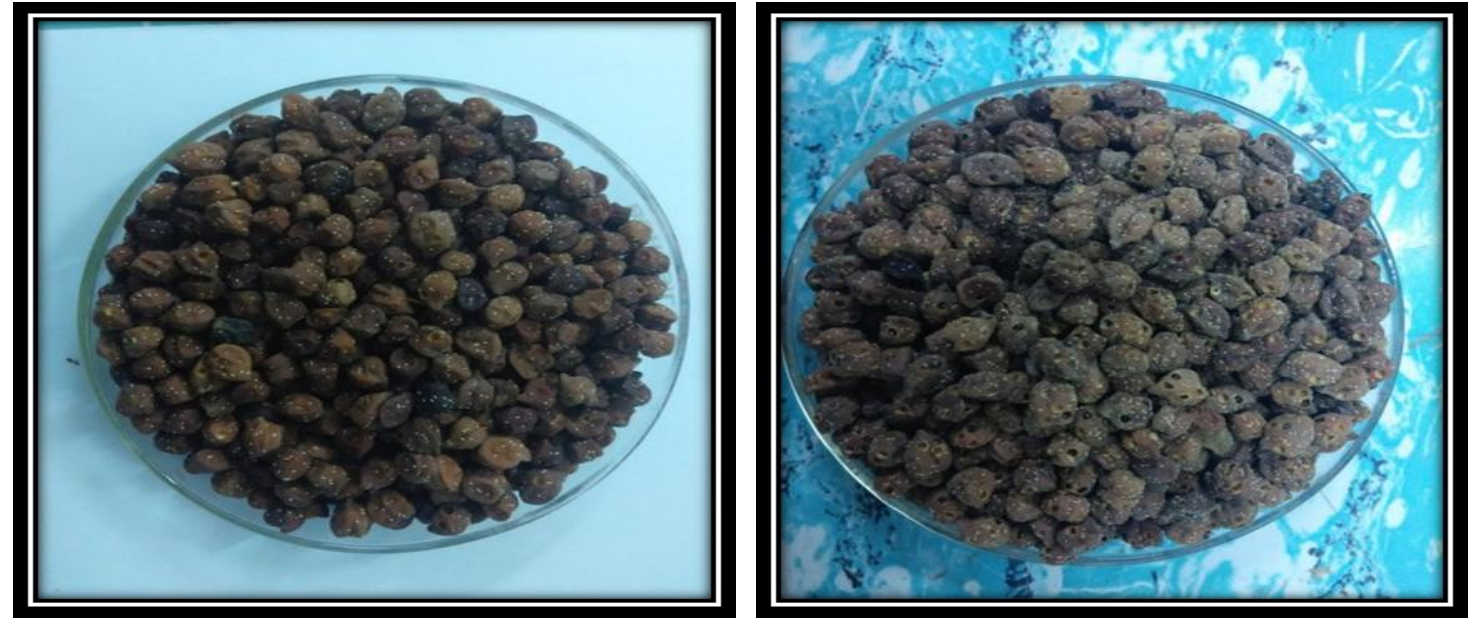

Fig.2.a Male pulse beetle

b. Female pulse beetle
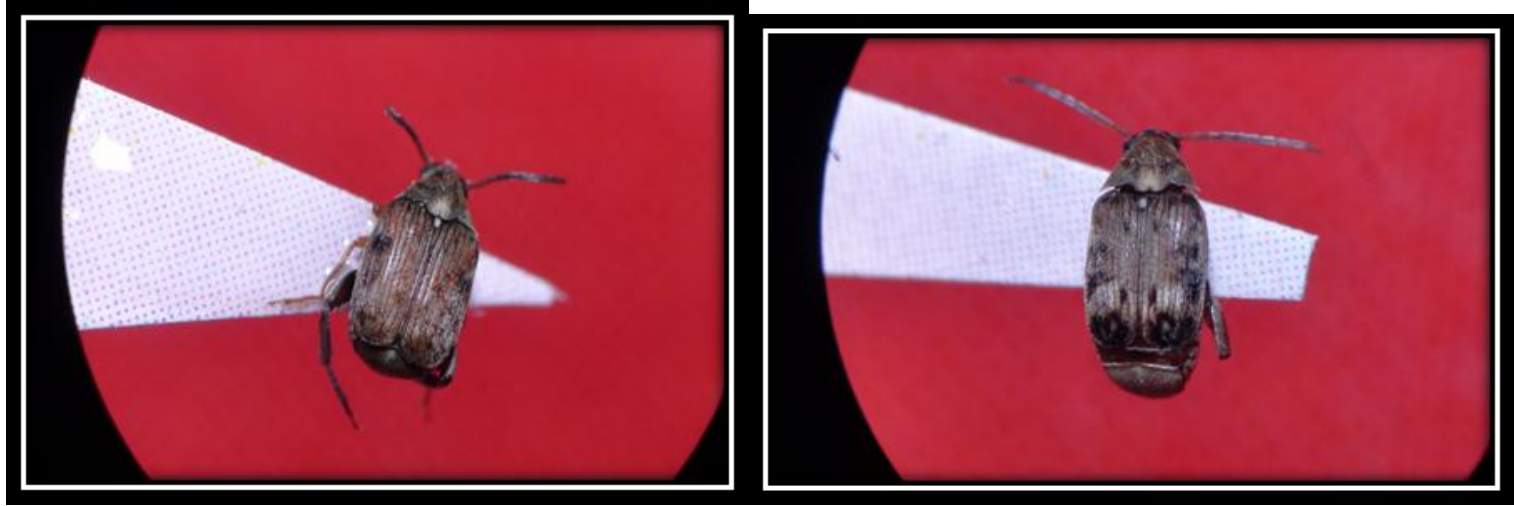

On the basis of present findings, it may be concluded that the genotypes showed some resistance against Pulse beetle (Callosobruchus chinensis) can be utilized for breeding programmes while developing new resistant varieties against pulse beetle.

\section{References}

Mookherjee, P. B., Jotwani, M. G., Yadav, T. D. and Sircar, P. (1970) Studies on incidence and extent of damage due to insect pests in stored seeds-II. Leguminous and vegetable seeds. Indian Journal of Entomology, 32(4): 350-355.
Dias, C. A. R. and Yadav, T. D. (1988) Incidence of pulse beetles in different legume seeds. Indian Journal of Entomology, 50 (4) : 457-461.

Adams, C. A. (1998) Deterioration of stored feed grains. Poultry and insect,37 : 32 $-36$.

Dobie, P. (1974) The laboratory manual assessment of the inherent susceptibility of maize genotypes to post harvest infestation by Sitophilus zeamais Mostch. (Coleoptera: Bruchidae). Journal of Stored Production Research, 10: 183-197.

Doharey, R. B., Katiyar, R. N. and Singh, K. M. 1987 Studies on the 
seed damage, weight and germination loss caused by pulse beetle in green gram Vigna radiata (L.) Wilczek. Bull Grain Technology, 20(1): 12-16.

Anandhi, P., Varma, S. and Sarvanan, L. 2008 Estimation of losses and evaluation of different storage containers against pulse beetle, Callosobruchus chinensis (L.) in Bengal gram. Journal of Insect Science (Ludhiana), 21(1): 40-43.

\section{How to cite this article:}

Kancherla Lakshmi Deepika, P.S. Singh and Singh, S.K. 2019. Screening of Certain Chickpea Genotypes against Pulse Beetle, Callosobruchus chinensis (L.) under Laboratory Conditions. Int.J.Curr.Microbiol.App.Sci. 8(04): 1190-1196. doi: https://doi.org/10.20546/ijcmas.2019.804.136 